\title{
STEFANO GASPARRI \\ The fall of the Lombard kingdom: \\ facts, memory and propaganda
}

It would only seem logical that a fact as important as the fall of the kingdom of the Lombards into the hands of the Frankish invaders, in 774, would find large echo in the sources. Unfortunately, this is not the case, at least if we limit ourselves to the more-or-less contemporary sources. On the other hand, if our time perspective is widened to the 9 th century, we find several interesting re-elaborations about the end of the independent Lombard kingdom. The Chronicon Salernitanum, composed at the end of the Ioth century, for example, comes into play painting a dramatic picture of the last king of Lombard descent, Desiderius, who appears dragged away in chains and blinded by his cruel vanquisher ${ }^{\mathrm{I}}$; moreover, we can't forget the Chronicon della Novalesa, dating approximately from the first half of the 9th century, which adds to the picture drawn above the legendary story of the battle of the Chiuse, and the fabulous memories of Desiderius' children: the unnamed daughter, traitress in name of Charles' love, and Adelchis, presented as a hero of super-human strength ${ }^{2}$. But, having said that, we must keep in mind that these are re-elaborations, that is to say narratives referring to situations and places distant from the year 774. Interesting as they may be, they must be placed outside of or, at the very least, at the margins of what my objective is: to examine the presentation of those crucial events within the context of contemporary witnesses or those composed immediately afterwards, in order to grasp

I Chronicon Salernitanum, ed. U. Westerbergh, Stockolm 1956, c. 9, p. I: Postquam Italiam rex Carolus venit, rex Italie Desiderius a suis quippe, ut dudum diximus, fidelis callide ei traditus fuit, quod ille vinctum suis militibus tradidit, et ferunt alii, ut lumine eum privasset.

${ }^{2}$ Cronaca di Novalesa, a cura di G. C. Alessio, Torino 1982, III, chs. 6-I4, pp. I42I6I, concerning Desiderius and his daughter (ch. I4 relates how Desiderius was blinded by Charles, a story appearing also in the Chronicon Salernitanum), and chs. 2I-23, pp. I68-173, about Adelchis (who, as we are told in ch. 2I, erat enim ipse a iuventute ... fortis viribus animoque audax et bellicosissimus) and his mother Ansa, portrayed as a pious queen, founder and patroness of churches and monasteries. 
precisely the relationships connecting the reality of the facts in the narrative, their immediate memory and their use as propaganda, moving ourselves through a labyrinth of told and untold things.

Before we begin, though, a clarification is needed in order to clear our field from a cumbersome comparison. In the Italian sources - but also in foreign ones - more or less contemporary to the events described, there is no re-elaboration of the events and of their significance in the year 774, that could be compared to that which occurred in Carolingian historiography after the 'coup d'etat' in the year $75 \mathrm{I}^{3}$. From a certain point of view, the conquest of the Lombard kingdom can almost be defined as a sort of 'non event'. A well-known fact about this needs to be kept in mind and bears repeating: the material available to us, coming out of Italy, is made up only of papal witnesses; outside of Italy, only the official voice of the Frankish annals can be added. What is flatly lacking is the voice of the Lombards or, as recently written by Walter Pohl, the "Lombard-Italic perspective", which itself would allow us to elude the perspective of the victors: i.e. the Franco-papal axis, whose narrative has survived through the modern manuals of medieval history. "Den Kampf um die Erinnerung hatten die Päpste in Italien gewonnen”, affirms Pohl again, and about this there is no doubt 4 .

If the propaganda of the victors in Italy is thus absolutely triumphant, why then doesn't the comparison with the year 75I, also known to us exclusively from the viewpoint of the promoters of the new Carolingian rule, work? This is, as a matter of fact, the only point in common between the losers of the years 75I and 774: besides the political and military battle they both have also lost the 'battle of memory'. The comparison doesn't work regardless, because, contrary to 75I, the year 774 isn't given particular importance in the sources. The Annales Regni Francorum, for example, the near-official source of the Carolingian palace, relate about the conquest of the Lombard kingdom with a few commonplace sentences'. After having described the military intervention up until the siege of Pavia, and after having made a long digression on the umpteenth campaign waged by Charles against the Saxons, the annals then dryly tell us about Charles'

3 On the subject see: Der Dynastiewechsel von 75I. Vorgeschichte, Legitimationsstrategien und Erinnerung, ed. M. Becher-J. Jarnut, Münster 2004.

4 W. Pohl, Das Pappstum und die Langobarden, in Der Dynastiewechsel..., p. I45-I6I, cit., pp. I45-I46.

5 On the Annales Regni Francorum within the context of Frankish historiography, see: R. McKitterick, History and Memory in the Carolingian World, Cambridge 2004, pp. 97-II9. 
return to Pavia, and of his overtaking both the city and king Desiderius, with his wife and daughter and all their treasures. After this catastrophe the Lombards in all Italian cities submit, Adelchis escapes to Constantinople and Charles, "ipsa Italia subiugata et ordinata", returns triumphantly to France, leaving a garrison in Pavia. All we have is a pure factual account of the campaign, the motivation of which is the invitation by Pope Adrian to intervene against Desiderius "pro Dei servitio et iustitia sancti Petri seu solatio ecclesiae"6. The place occupied by the campaign against the Saxons, in the economy of the annals, appears more important than the conquest of the Lombard kingdom.

In the Italian sources we are faced by an altogether different situation. Focus, though, is not so much placed on the kingdom's fall in the year 774 as on the entire forty-years period that spans from Stephen II to Adrian I. At this point, though, it is necessary to make a distinction.

Papal propaganda of the 8th century, as it's well-known, takes the form of two main types of written sources: the biographies of the Popes of the Liber pontificalis, whose circulation was immediate and therefore more or less strictly contemporary with the events they narrated, and the letters sent, in their large majority, to the Frankish rulers 7 . In the case of the latter, however, the main bulk is represented by the letters gathered in the Codex carolinus, whose composition was ordered by the same Charlemagne in the year 79I, with the aim of preserving the texts which, due to their nimia vetustas and to man's negligence, were in part diruta atque deleta; this means that it deals with a selection of letters made at the Frankish court and that the resulting image is not necessarily what the papal court would have wanted to give about the events and the role played in them by the Popes ${ }^{8}$.

Even without undergoing a detailed examination of it, however, a fairly complete idea can be gathered from the papal collection. The focus of the pontifical epistolary activity is not placed on the facts of the year 774, not even directly mentioned in the letters preserved. The main focus, instead, is placed on three other moments or events. The first is Aistulf's offensive against Rome in the year of 756 , the second, during the years

6 Annales Regni Francorum, ed. F. Kurze, MGH, Scriptores rerum Germanicarum in usum scholarum, Hannoverae I895, pp. 34-40.

7 Le Liber Pontificalis. Texte, introduction et commentare, ed. L. Duchesne, I, Paris I886. About the circulation of the Liber, see: O. Bertolini, $I l$ Liber Pontificalis, in La storiografia altomedievale, Settimane del CISAM, I7, I, Spoleto I970, pp. 387-455.

${ }^{8}$ Codex Carolinus, ed. W. Gundlach, MGH, Epistolae, III, Hannoverae I892, pp. 469-657; the reasons behind the editing of the collection of letters are listed at the beginning, p. 476 . 
770-77I, is the negotiation for the marriage of one of the two Frankish rulers with one of Desiderius' daughters, and the third is the attempt at general rebellion of the Lombard dukes against the Franks in the year 776, and its after-effects in the following years. These are the moments of greater tension and danger in the situation of Italy, in which - what is more without obtaining full support from the Franks - the Popes ask for help and political and military intervention. These are also the moments in which the language used in the letters reaches extremely harsh and violent levels.

The misdeeds that the nequissimus Haistulfus is accused of by Stephen II, in February of 756, are terrifying. The fields outside of Rome are devastated by iron and fire, houses are burned and destroyed, the churches are set on fire and sacred images are burned and cut into pieces by the swords, the consecrated hosts are thrown into contaminated containers by the Lombards and eaten together with the meat ("cibo carnium copioso saturati comedebant eadem munera"); then the Pope continues with the story of destruction and systematic looting of all the sacred furnishings, the killing of the monks, the violence done to the sanctimoniales feminae, the destruction of the domus cultae, both of St. Peter as well as of all the Romans, the theft of the animals, the destruction of the vineyards "fere ad radices", the killing or deportation into slavery of the country servants, winding up with the massacre of infants being torn from their mothers' breasts. The Lombards of Aistulf caused more damage than was ever brought about by the pagans to the point where it can almost be said, concludes Stephen, that the same stones, seeing our desolation, "ululant nobiscum"9.

What we have before us, then, is a piece of inflated propaganda, which culminates in another missive, dating from the same time as the previous one and sent by Stephen in the name of St. Peter, where the saint invokes protection by the Franks on the populus meus peculiaris against the attacks by the Lombards, defined as foul persecutors and "trespassers of the Holy Scriptures" Io. This first body of letters clearly identifies, on behalf of the papacy, a critical phase that terminates only with the death of the tyrant

9 Codex Carolinus..., 8, p. 495. The letter belongs to a group of five (ns. 6-Io, pp. 488-503), composed between 755 and February, 756, denouncing the above mentioned phase of Aistulf's anti-Roman policy.

Io Codex Carolinus..., Io, pp. 50I-503.; about the idea of populus peculiaris, see O. Bertolini, Le origini del potere temporale e del dominio temporale dei papi, in I problemi dell'Occidente nel secolo VIII, Settimane del CISAM, 20, Spoleto 1973, pp. 248-255, and G. Arnaldi, Le origini del Patrimonio di S. Pietro, in Storia d'Italia, VII/2, UTET, Torino I987, pp. IOO-IO3. 
Aistulf, sequax diaboli, devorator sanguinum christianorum, ecclesiarum Dei destructor, who in the end, struck by divine forces, precipitates into hell's abyss $^{\text {II }}$. Equally critical is the phase of the marriage between a Frankish prince, Charles, and one of Desiderius's daughters, a phase immortalized by the famous letter in which the Pope at the time, Stephen III, defines the Lombards as "perfida ac foetentissima gens", "that cannot even be included as part of the peoples, whose natio is certain to have originated the descent of lepers"'I2. The letter is too well known to be further commented on here, if not to underline the absence of the Lombard princess' name, which corresponds to a precise strategy of damnatio memoriae, unyieldingly followed by papal and Frankish sources, a strategy that would end up truly cancelling out the name of Desiderius's fourth daughter, the only one destined to remain nameless ${ }^{\mathrm{I} 3}$.

The dangers of a Lombard recovery after the defeat of Desiderius (the third crucial moment referred to earlier) are also given great importance in the papal collection, but here the tone never reaches the level of verbal violence of the two previous episodes. Also indicative of the papal view is the fact that the revolt of Friuli never appears in the letters; on the other hand, this is the only episode cited in the Frankish annals, evidently well evaluating the danger of the armed opposition of the powerful north-eastern Lombard duchy ${ }^{\mathrm{I}}$. But in the Codex Carolinus the dominant perspective is a central-southern one, and therefore the principle exponents of the plot, rather than the duke of Friuli, Rotgaud, are the dukes of Spoleto, Benevento and Chiusi. In reality, however, the real protagonist is another one, always ready to break onto the scene, though he actually never does manage to do it: Adelchis. Adrian I uses strong expressions when describ-

II Codex Carolinus..., II (March-April 757), pp. 505-506: as a substitute for Aistulf, writes with satisfaction pope Stephen, Desiderius, vir mitissimus, was elected king of the Lombards, also thanks to the decisive support of Pepin's envoy: Fulrad, abbot of St. Denis.

${ }^{12}$ Codex Carolinus..., 45 (770-77I), pp. 560-566, quote at p. 56I. The violence of the anti-Lombard insult can be wholly appreciated when placed beside the laudatory expressions dedicated to the Franks and personally to Charles and Carloman: praecellentissimi filii, magni reges ...vestra preclara Francorum gens, quae super omnes gentes enitet, et tam splendifua ac nobilissima regalis vestrae potentiae proles ... (p. 56I).

I3 S. Gasparri, I Longobardi fra oblio e memoria, in Studi sul Medioevo per Girolamo Arnaldi, ed. G. Barone-L. Capo-S. Gasparri, Roma 200I, pp. 262-273, where the different position held by J. Nelson, (Making a Difference in Eight-Century Politics: The Daughters of Desiderius, in After Rome's Fall. Narrators and Sources of Early Medieval History, Essays presented to Walter Goffart, ed. A. Callander Murray, Toronto I998, pp. I7I-190) is also related and discussed.

${ }^{14}$ Annales Regni Francorum..., pp. 42-45 (775-776). 
ing him, calling him: the nefandissimus Adelchis, son of the tyrant Desiderius, insolent, nequissimus, arrogant, iniquitous, perfidious; the fear is that the conspirators, with the help of the Greeks, can "Langobardorum regem redintegrare", or reinstate Adelchis to the throne after having taken Rome, taken away the tabernacle of St. Peter and taken the Pope himself as prisoner ${ }^{\mathrm{I}}$.

Differing from the two previous episodes, though he is evidently worried, the language relatively measured used by Adrian shows that in this case he doesn't doubt to receive Charles' support. He, therefore, needs only to clarify the dangers of the situation and does not have to convince the Frankish ruler to be on his side, something that appeared necessary instead to his predecessors who, moreover, were not sure of the results of their efforts. Naturally, the concept of 'measured', referred to in the language of the papal chancery as it is reflected in the Codex carolinus, needs to be carefully understood. For example, a heavy adjective appearing in the collection of letters such as nefandissimus automatically clicks for all those finding themselves in opposition to the objectives pursued by the Roman church in that period. Thus nefandissimus doesn't only refer to the Lombards, their kings and their dukes, but also to the people of Benevento, Spoleto, the Greeks, the Neapolitans and the archbishop Leone of Ravenna. All these people lose such adjective, however, even after a very brief period of time, if their behaviour changes ${ }^{16}$. In such conditions it is evident that nefandissimus loses its actual semantic value and becomes purely a political label, no longer having moral connotations, simply identifying the belonging to a side adverse to the Pope's. This also explains why, in the peak moments of propaganda (756 and 770/I), papal language must throw itself into the description of a redundant series of horrors committed by the adversaries, giving to its Frankish readers the sense of finding themselves in front of a decisive moment where taking sides without any hesitation is necessary ${ }^{17}$.

is Codex Carolinus..., 57 (775 ex.), pp. 582-583. on Adelchis see Codex Carolinus..., 80 (787-788), pp. 6I2-6I3.

${ }^{16}$ Examples can be found everywhere in the Codex Carolinus, making it impossible to quote them all. However, it can be useful to quote here a clear example of an extremely violent invective - which makes us understand how 'nefandissimus' could be considered a moderate insult - what's more thrown at an enemy of small political import, i.e. the duke of Chiusi Raginaldus, who menaced the Papal possessions in Tuscia and is therefore called: perfidum illum et seminatorem zizaniorum atque instigatorem umani generis emulum, follower and emulator, that is, of the Devil (Codex Carolinus..., 58 (776, post -February 7), p. 583.

${ }^{17}$ Reference is made here mainly to two letters, already examined, the one describing the devastation caused by Aistulf near Rome, and that stigmatising with harsh words the pending marriage negotiations between Franks and Lombards (see supra, notes II and I2). 
It must be stressed that the same language is used by other ecclesiastic sources. During the years immediately prior to 774 , in describing the oppression suffered by the Lombards (heavy fiscal burdens, restrictions by bishop's ordinations), the patriarch of Grado, Giovanni, uses expressions such as gens perfida Langobardorum, sevissimi Langobardi, and invokes Adrian I to save him and his church "de manibus gentis Langobardorum"I8: the political rhetoric is the same used by the Popes. However, another observation is also possible. An inattentive observer, who was to read one after the other - without taking note of the dates - the letter written by Giovanni and the famous epistle sent in the year 59I to emperor Maurizio from the bishops of the diocese of Aquileia, reunited in the synod of Marano (in the Venetian lagoon), would not notice any substantial difference from the standpoint of political language in the way the Lombards are presented, as gens estranged from the civil world, in the $6^{\text {th }}$ and in the $8^{\text {th }}$ century: and the bishop's letter of the 6th century appears less harsh therefore not as far off from reality - than the one of two centuries later ${ }^{19}$.

Doggedness persists in the political language used by the church, both in the 6th and 8th centuries, and it appears to be very solid - even if this is abandoned at times ${ }^{20}$. Perhaps the roots of this language can be found precisely at the end of the 6th century, during the age of Pope Gregory the Great, who in a famous letter enjoyed about the death of the nefandissimus king Autari and in the Dialogi spoke of the effera Langobardorum gens, that in nostra cervice crassata est ${ }^{2 \mathrm{I}}$. That means that the first encoding of this antiLombard papal (ecclesiastic) language possibly took place during the papacy of Gregory I. I don't believe it is coincidental that during the age of Hadrian I, between the years of 772 and 795, encompassing the decisive period at the centre of our attention, a first collection was made of Gregory the Great's letters - the so-called Hadrian collection - heavily reducing the original body from twelve volumes to two and at the same time putting a shorter and 'official' version of the registrum into circulation ${ }^{22}$. Looking

${ }^{18}$ Epistolae Langobardicae Collectae, in MGH, Epistolae..., III, I9 (768-772), pp. 7II-7I3.

I9 Gregorii I Papae Registrum Epistolarum, in MGH, Epistolae, ed. P. Ewald e L. M. Hartmann, I, Berolini I887, I, I6, pp. I7-2I.

${ }^{20}$ Compare the entirely different language used, not only by Gregory in his letters to the royal couple of Agilulf and Theodolind, but also by the patriarch John with king Agilulf; Gregorii I Papae Registrum..., I, IV, 4, 33 (593), pp. 236 e 268-269, and Epistolae Langobardicae Collectae ..., I (607 ca.), p. 693.

2I Gregorii I Papae Registrum..., I, I, I7 (590); Gregorii Magni Dialogi, ed. U. Moricca, Fonti per la storia d'Italia, 57, Roma I934, III, 38, p. 226.

${ }^{22}$ R. Markus, Gregory the Great and his World, Cambridge 1997, pp. I4-I5 and 206-209. 
back at the end of the 8th century, it is possible to think that the relationship between Gregory and the Lombards, in that period, was either intended, used or presented as a precedent, since it refers to a seriously tense phase, which was placed at the outset of the period of Lombard dominion, while what we are speaking of places it precisely at the end. The parallelism is strong and it's not by chance that the only possible parallel to the story of the terrible devastations brought on by Aistulf be the heartfelt description by Gregory (in his letters and homilies) of the Romans, taken into slavery and bound at the neck more canum, and of farmers who escaped to Rome with their hands cut off 23 .

Carried out following the impulse given by Pope Adrian I, the editing of an official version of the Gregory the Great's registrum, could therefore be considerd a part of a complex work of propaganda that found another peak in the Popes's lives of the Liber pontificalis. Before examining the Liber, though, two more quick remarks are needed concerning the papal letters, useful for understanding the filter they present between the reality of the events and their representation.

The first remark is the sharply two-sided treatment reserved to Desiderius. He is mitissimus, excellentissimus filius noster in the early period immediately subsequent to his election (sometimes even later), which occurred on impulse or at least with Frankish support; he instead becomes cruel and impious when he refuses or, better, postpones giving back the land and the civitates promised, those iustitiae beati Petri that Girolamo Arnaldi rightly identified, as the authentic, narrow-minded, obsession dominating all diplomatic activity by the papal court in the late 8th century $^{24}$. Nonetheless, the treatment towards Desiderius moves on to a more political level than in the past, although the devastations orchestrated by him in the region around Rome are made evident (without the description of particular horrors, however) ${ }^{25}$. If the Pope Paul I highlights - in a way which has by now become traditional - the callida versutia and falsehood of the Lombards, in fact, he also acts on different planes. In the year 758 he sends a letter to Pippin in which he tells him about the peaceful

23 Gregorii I Papae Registrum..., I, V, 36 (letter composed on June 595, to the emperor Mauritius), p. 3I9, and Id., Homilia in Ezechielem ultima, II, IO, ch. 24.

24 G. Arnaldi, Il papato e l'ideologia del potere imperiale, in Nascita dell'Europa ed Europa carolingia: un'equazione da verificare, Settimane del CISAM, 27, I, Spoleto I98I, pp. 34I-407. For an example of positive representation of Desiderius (already examined) see supra n. II.

${ }^{25}$ Codex Carolinus..., 20 (c.760), p. 521: et plures depredationes ex tunc atque multa et inaudita mala in nostris inmittit finibus. 
encounter ad limina apostolorum with Desiderius and where, aside from edifying talks, a first agreement had been be reached on the return of the contested territories. Shortly after, though, Pippin's messenger, Rodbertus, carries another letter affirming the contrary. In it the Pope begs the Frankish king not to release the hostages and mentions the malitia (another Gregorian term) of Desiderius and the Lombards, revealing that the previous letter - whose contents are to be considered untrue - had to be written because otherwise the Lombard king would have never allowed his messengers to reach the court of $\mathrm{Pippin}^{26}$. Around the year 760 , Paul himself writes once again to Pippin complaining of continual violations by Desiderius to the pacts with the Franks, saying to have received letters from them containing ghastly threats made towards him, letters that he attaches to the missive in question ${ }^{27}$. These letters, unfortunately, have not been preserved and therefore we cannot judge about their authenticity: moreover, it is probably legitimate to doubt it a priori. We have before us, therefore, a skilful political management of the event by the papacy which uses different tools, letters which are cover up and letters which are fake.

The second consideration is connected with what was affirmed earlier: the fall of the Lombard kingdom is purposely omitted from the letters conserved in the Codex carolinus. As a matter of fact, it is not represented at all in the two letters relative to the year 774. Nor are the events of the fall of Pavia ever mentioned: there is only a brief, very indirect mention in a letter written by Adrian in 775. In this last case, although the facts are very recent, the Pope's first preoccupation is to ask Charles, from whom he received news, to fulfil the promises made to the Roman church so that his protection by St. Peter can increase. Only at this point does Hadrian add that - as a consequence of protection and intervention by Peter - God "gave you the victory and ordered that the kingdom of the Lombards be given over to your power". He continues by saying that with his help Charles will be able to subdue "the other barbaric nations", an obvious reference above all to the open wound of the conflict with the Saxons ${ }^{28}$. There is nothing more about the year 774 , if not - in another

${ }^{26}$ Codex Carolinus..., I6, p.513-514, where the Lombard king is called (p. 513) excellentissimus filius noster, and I7, pp. 514-520 (both letters composed c. 758), where we find reference to his violent actions, instead - quae in his partibus a Desiderio Langobardorum impie peracta sunt atque crudeliter perpetrata - (p. 515) and to his duplicity (p. 5I7).

27 Codex Carolinus..., 20, pp. 520-522.

${ }^{28}$ Codex Carolinus..., 53, pp. 574-576, cit. at p. 575: eius (scil. Beati Petri) sacris interventionibus omnipotens dominus Deus noster victoriam tibi tribuit regnumque Langobardorum tuae tradere iussit potestatis dicioni. 
letter of 775 - blaming Charles for the ambiguous behaviour of his envoys, who aren't taking care of the papal interests about the Sabine patrimony, claimed by the church of Rome. In this letter Hadrian reminds the Frankish king that it's not for the conquest of gold, gems, silver and men that he sustained tantum fatigium together with the entire Frankish army, but it was instead to demand iustitae beati Petri, to exalt the church of Rome and re-enforce the Pope's safety ${ }^{29}$. This was a reference to the motives of the campaign in the years $773-774$ and of the conquest of the Lombard kingdom, which, however, are not even named in an explicit way. Beside another similar but softer passage in another letter, we must keep in mind the solar expressions of Hadrian I in one of the two letters attributed with some certainty to the end of 774, where he throws himself against the arrogance of the archbishop of Ravenna, Leo, who took advantage of the situation - as soon as Charles returned to France - by submitting the civitates of the Emilia region to its authority. He then puts the following affirmations into the mouths of his enemies, who take advantage of the difficulties of the moment to defame him: "What did you get out of the Lombard people being destroyed and subjugated to the Frankish kingdom?" This is how Hadrian reads the events of the decisive two-year period between $773-774^{30}$. From this viewpoint, they don't represent an epoch-making turn, but a passage in dealing with a political, military and territorial affair which began around the year 750 and still had not been solved.

The other main source available to us, the Liber Pontificalis, has perhaps been more exploited than the Codex Carolinus. However, a cross reading of the two sources allows for interesting observations. For example, some unmistakable coincidences can be highlighted. The Lombards and their kings, after a lengthy pause, lasting more than a century, reappear significantly in the Liber only in Pope Zacharias' biography. The treatment reserved to Liutprand is just political, if we put aside the final exultance for his death (when the Pope defines him as an "snarer and persecutor"); a slightly incongruous exultance, though, with respect to the general tone used about his life which could, therefore, have been inserted in a subsequent stage, at the end of the brief confrontation between Zacharias and Liutprand's nephew, Hildeprand, rex malivolus, the king who embodies

29 Codex Carolinus..., 56, pp. 580-58I.

30 Codex Carolinus..., 49, pp. 567-569, cit., p. 568: quid vobis profuit, quod Langobardorum gens est abolita et regno Fracorum subiugata? Et ecce iam nibil de his, quae promissa sunt, adimpletum est ; insuper et ea, quae antea beato Petro concessa sunt a sanctae recordationis domno Pippino rege, nunc ablata esse noscuntur. Apparently, Hadrian thinks that the situation of the Church's estates has become even worse after the Frankish conquest. 
the first real break between the papacy and the Catholic kings of the Lombards ${ }^{31}$. The phase represented by Ratchis' reign ended not only without serious difficulties, but even with the king's conversion to monastic life $^{32}$. The first tough moment of confrontation between Rome and Pavia is represented, also in the Liber, as the one between Stephen II and Aistulf.

The biography of Stephen II can be read in perfect counterpoint to the very harsh letters sent by his chancery. Because of the weight of the political threat represented by Aistulf, who had not only refused to carry out the usual territorial 'restorations', but had also occupied Ravenna, stopping short of submitting Rome, the Pope defines him with all the possible negative adjectives: arrogant, vile, extremely cruel and atrocious, blaspheme, evil, iniquitous, pestiferous, tyrannical; his action is characterized by cruelty and cunning, and his heart of stone is not softened by the heartfelt appeals made by Pippin and the Pope, who try to convince him to negotiate and avoid bloodshed. The action which characterizes him more than anything else is the retaliation against Rome in the year 756 - the same one described with heartfelt tones in the letters - during which a cospicuous theft of relics is carried out. This event, in fact, had been a transferral of relics to other centres (such as the relics of St. Sylvester to Nonantola), placed in the Lombard kingdom, to strengthen their spiritual defences; but the episode was used by the biographer in order to present a truly diabolical image of Aistulf. It is noteworthy to observe that, in complete reversal of the treatment reserved to Liutprand, the only glimmer of spiritual sensitivity is shown by Stephen II's biographer at the moment of Aistulf's death while hunting, when he calls him infelix (but in the following line Aistulf once again becomes nequissimus)33.

The change of tone marked by the life of Stephen II fully coincides with the evidence of the Codex Carolinus: the heated period began around 750 . However the following lives of Paul I and Stephen III, between 757 and 772 , cannot be easily evaluated. The former is completely void of political references, the latter is divided into two parts the first of which is entirely dedicated to the events immediately following Paul's death, that

${ }^{31}$ Le Liber Pontificalis...cit. n. 7, pp. 426-439, comments about Liutprand and Hildeprand's end can be found at p. 43I. A comment on the relationship between Zacharias and Liutprand, focusing especially on their meetings, at Terni and at Pavia, is found in S. Gasparri, Roma e i Longobardi..., pp. 235-239.

${ }^{32}$ Le Liber Pontificalis..., pp. 43I and 433-434.

33 Le Liber Pontificalis..., pp. 440-462 ; p. 454: ipse infelix Aistulfus quodam loco venatione pergens, divino ictu percussus defunctus est. 
is the usurping carried out by Constantine, an exponent of the aristocracy of Roman Tuscia34. The extremely difficult internal situation in Rome, torn by infights between the parties to gain local power, reverberates in the second half of the life, but now Desiderius progressively appears in its foreground 35 . Represented as a completely trustworthy partner, as a support even, in the first part, he progressively takes the upper hand in the second, to the point of imposing on Stefano to give up to his people two powerful Romans whom the Pope owed the election to, the primicerius notariorum Cristoforo and his son Sergio ${ }^{36}$. Desiderius in this case is defined as protervus, he shows a maligna sevitia; but all in all we are dealing with expressions that we could define as routine. In reality, in all the biography Desiderius and Stephen are presented as politically connected, even if the king's military superiority is evident, at the point that Desiderius occupied St. Peter and held the Pope prisoner. It is true that Desiderius doesn't give back the iustitiae of St. Peter, but the blame is attributed above all to his "very wicked" counsellors and first and foremost to the priest Paulus Afiarta. It is clear that the caution of the two biographies of Paul I and Stephen III, the first of which, not by chance, describes only the ecclesiastic activity of the Pope, expresses an extremely difficult moment for the Popes, weakened from within by the aristocratic opposition and then taken aback by the alliance between Desiderius and the Franks, which culminated in the marriage between Charles and the daughter of Desiderius. While the famous letter by Stephen III expresses a counter-offensive to avoid a potentially fatal event, his Life is silent about it. The Franks are apparently absent from it.

Things change with the life of Adrian I: the knot is loosened at this point and the Lombard question is on its way to resolution ${ }^{37}$. After Carloman's death (december 77I), Charles has become the only ruler of the Franks and Desiderius' daughter has been disowned. At this point the political dynamics began again to follow the previous tracks, those of the age of Stephen II, although Desiderius attempted to manoeuvre the sons

34 Le Liber Pontificalis..., p. 463-465 (Life of Paul I) and pp. 468-48o (Life of Stephen III).

35 The second part of Stephen III's Life begins at p. 473.

${ }^{36}$ G. Duchesne, I primi tempi dello Stato pontificio, Torino 1967 ( $\mathrm{I}^{\text {st }}$ French edition I898), pp. 5I-60, and O. Bertolini, Roma di fronte a Bisanzio e ai Longobardi, in Storia di Roma, IX, Istituto di studi romani, Bologna I94I, pp. 622-663.

37 Le Liber Pontificalis...cit., pp. 486-499 (reaching up to the fall of Pavia at the hands of Charlemagne). 
of Carloman ${ }^{38}$. Only at this point Desiderius is, "a posteriori”, identified as the real responsible for the end of Christophorus and Sergius, thus absolving Stephen III. The king was made to answer to the messenger sent by Hadrian that his compliance with his former promises about territorial restoration, made to Stephen, was not necessary because: "sufficit apostolico Stephano quia tuli Christophorum et Sergium de medio", since he was dominated by them, and that he protected the Pope from a hypothetical military intervention by Carloman, who, according to Desiderius, was in alliance with both of them 39 . The brutality of the answer defines the figure of Desiderius in the Life of Hadrian: Desiderius is not the tyrant Aistulf, animal-like in his leonine deeds and almost possessed by the devil, but is an arrogant king, blinded by pride, whose heart of stone doesn't soften even when faced with the heartfelt appeals to reason uttered by the Pope and Charles. The epilogue of war, the campaign of conquest and the taking of Pavia are therefore the logical conclusion to the king's behaviour. If Desiderius therefore isn't demonic, the rhetoric of the papal biography, however, once again reaches elevated heights, though from a different side, forcing it to display divine favour behind the work done by Charles ${ }^{\circ}$.

Finally, the events of the year 774, which were absent from the correspondence, are described here. The parallelism is evident between the description of the first campaign of Pippin twenty years earlier ${ }^{4}$, and Charles' one, even if the emphasis, such as in the description of the two Lombard kings, is placed on different aspects. Divine favour brings victory to the Franks in both passages. In the first case, though, the intervention of God is mentioned only to explain how these men, so few in numbers (it was only the avant-garde of Pippin's army), could have won. In the

${ }^{38} \mathrm{~J}$. Nelson, Making a Difference... cit. n. 13, p. I82, on the political reasons behind the repudiation, connected to Charles' need for connections, through the marriage with Hildegard, with the aristocracy of the eastern part of the kingdom, already connected to his brother Carloman.

39 Le Liber Pontificalis..., p. 487.

$4^{\circ}$ Le Liber Pontificalis..., p. 499: dum ira Dei super omnes Langobardos qui in eadem civitatem erant crassaretur atque seviret, et plus de languoribus seu mortalitatis clade defecissent, ita Dei nutu tandem civitatem simulque et Desiderium Langobardorum regem atque cunctos qui cum eo erant ipse excellentissimus Francorum rex con prehendit, et suae potestati cunctum regnum Langobardorum subiugavit. To complete the picture, Desiderius and Ansa are deported to France.

${ }^{4 \mathrm{I}}$ Le Liber Pontificalis..., pp. 449-45I, where we are told that: iustus iudex dominus Deus et salvator noster Iesus Christus victoriam paucissimis illis tributi Francis. 
second, instead, God instils terror in the hearts of Desiderius, Adelchiss and all the Lombards, who even run off without fighting: the image is evidently stronger. It is reinforced further on, when the taking of Pavia is spoken of, where it is the ira Dei that decides the outcome of the confrontation and brings about the fall of a city that the Franks had never before been able to take and which now offered no resistance, shaken by a hard pestilence ${ }^{42}$.

This is the story of the year 774 told in the Liber Pontificalis, which, however - in this respect similar to the letters - seems more interested in describing the events that took place in central Italy resulting from the victory of the Franks, portraying the repeated submissions by the various civitates, with the magnates of which going to Rome and swearing allegiance to St. Peter43. It's the image of a Lombard kingdom that is crumbling internally, even before the decisive military defeat determined by the taking of Pavia (the event which makes the difference between 754 and 756), and it is certain that, more than divine wrath, it was this process that provoked the fall of the kingdom's capital. Despite it's brevity, however, what is just described represents the only official version by the papacy about the conquest of the Lombard kingdom by the Franks.

Between the Frankish collection of papal letters and the Liber Pontificalis, therefore, similarities and differences can be made out. The anti-Lombard propaganda in both cases is expressed in two strong points placed both at the outset and conclusion of the decisive period, while the period of tension with the Franks which stands out in the collection of letters is only hinted at in the Liber through their absence in the central part of this same period, and by mention of possible hostility on Carloman's side. Above all, it's the ending that is different. Even if only briefly, the taking of Pavia appears in the Liber, followed by the story of the submission of some cities in central Italy, after which the Life of Hadrian turns completely to the religious-ecclesiastic record, hiding all subsequent developments; the fall of Pavia, instead, is ignored by the letters and the following years are dramatically placed at the centre of papal action, up until the end of the eighties of the 8th century44.

${ }^{42}$ Le Liber Pontificalis..., p. 495: the Franks were ready to return home, in order to avoid spilling of blood, but God misit terrorem et validam trepidationem in cor eius vel filii ipsius Adelgisi, scilicet et universorum Langobardorum; see also supra, passages quoted in ns. 40 and $4 \mathrm{I}$.

43 Le Liber Pontificalis..., pp. 495-496.

44 Le Liber Pontificalis..., pp. 499-514: between 774 and 795, the year of Hadrian's death, no mention is made about the political situation in his biography, notwithstanding the fact that those were, undoubtedly, turbulent times characterised by the revolt of the Lombard dukes in the North and Middle of the peninsula, the constant menace of the citizens of Benevento, and of Adelchis, in the South, together with the 
The impression is that in the papal biographies the propagandist aim is the main one, because the Pope's lives were supposed to circulate after their death of the Popes, often when the games were over. If the biographies are silent on important questions, such as in the life of Paul I with respect to the political situation, or are cautious, such as Stephen III'life concerning Desiderius, it's exactly because the situation was still too fluid to allow the taking of clear and precise standpoints 45 . The epistles are also fed with propaganda from their viewpoint, but as an immediate tool for political struggle, above all for obtaining consent in the Frankish court. It appears less important for them to praise even recent events, but already past, like the kingdom's fall, and necessary, instead, to place more emphasis on imminent dangers: those represented by an Aistulf still untamed or those embodied by Adelchiss and by the various rebel duchies.

A letter sent by Hadrian I to the abbot of St. Denis, Maginarius, proves once again this feature of the collection of letters as a useful and flexible fighting tool of immediate political propaganda. In order to present to Charles the misdeeds of several bishops that contest a privilege granted him by StH. Denis, the Pope doesn't hesitate to acknowledge that the Lombard kings, "vel si ex eis quidam perfidi fuerant et in superbia eorum pro sancta ecclesia Romana perierunt" (a very dry epitaph regarding the end of the independent Lombard kingdom), however they accepted fideliter the privileges of the church in their territories and conserved them with veneration ${ }^{6}$. It is an affirmation that clashes, shamelessly, with almost half a century of anti-Lombard propaganda and that Hadrian would never have made in the heated period of the fight. At this point, however, we are close to the year 790 and, having filed away the danger represented by the Lombard kings of Pavia, their antique devotion, which was never before made evident, can be useful to defend the papal interests of the moment.

numerous cities still not subjugated to the papal authority, the too-independent northern bishops, and the "restorations" which the Franks kept on a purely theoretical level: Codex Carolinus..., 49-94, pp. 567-636.

45 Cf. supra, n. 34 e 35 and O. Bertolini, Il Liber Pontificalis..., cit. n. 7.

${ }^{6}$ Epistolae selectae pontificum romanorum, in MGM, Epistolae, V, ed. E. Dümmler, Berolini 1899 , p. 4 (788-792). Obviously the remarks made on the nature of the papal letters can be considered valid only for those letters preserved, mainly within the Codex Carolinus, and therefore consciously selected by the Frankish court. On the whole, though, the general impression is that, even if laudatory letters composed by the popes and addressed to Frankish kings existed (but we would be tempted to ask ourselves why they were not included in the codex), the main drift of the letters, at least in terms of propaganda, seems to be the one portrayed above. 
The propagandistic value of the Liber Pontificalis is proved also by the fact that it circulated in different versions, some of which have particular value. First of all there is the so-called 'Frankish recension', carrying an insertion in the life of Gregory III, relating of the Pope's request for help to Charles Martel47. It is a later insertion regarding an action without result, on the spur of the moment, but that, in the light of subsequent events, acquired great releance. The added passage is certainly derived from a Frankish environment and from Frankish sources. It's not just by chance, in fact, that the first letters of the Codex carolinus make reference to this appeal, despite its remaining unheeded at that time ${ }^{4}$. At the end of the 8th century, at the moment in which the code was created at Charles' court, this episode constituded an important precedent, and therefore was highlighted in the picture which was a posteriori reconstructed by the Carolingian propaganda. With the 'Frankish version', the Liber also recovered the episode and it did so during a critical time, that is the confrontation between Stephen II and Aistulf. It should be kept in mind that the Life of Stephen is constructed as a form of justification for his appeal to the Franks; this is why the precedent of the age of Gregory, neglected from the outset due to general political uncertainty, is rediscovered right at that time 49 . Both sources use a secondary episode to prove their point, highlighting it at different times, thus showing partly differing strategies .

The relationship between the Frankish recension of the Liber and the reflection on political and propagandistic strategies that tie themselves to the facts of 774 could appear limited, but this isn't the case. This version, stressing the justification of Pippin and Charles' military interventions in the light of re-

47 Le Liber Pontificalis..., p. 420: Liutprand had already pitched camp outside Rome's wall, the Roman countryside was subjected to raiding and looting, many noble Roman citizens were forced to swear allegiance to the Lombards, their hair cut and their bodies clothed after Lombard fashion; Gregory III, lost all hope, sent envoys by sea to Charles Martel with the keys of Saint Peter ut eos a tanta oppressione liberaret. The same version appears in the Chronicarum quae dicuntur Fredegarii Scolastici continuationes, ed. B. Krusch, in MGH, Scriptores rerum Merovingicarum, II, Hannoverae I888, pp. I78-I79, where it is related that Gregory promised Charles ut a partibus imperatoribus recederet et Romano consulto (scil. consulato) praefato principe Carlo sanciret.

${ }^{8}$ Codex Carolinus, ns. I-2, pp. 476-479.

49 R. McKitterick, History and Memory... cit. n. 7, pp. I2I-I22: the insertion is found in a Viennese codex (ÖNB cod. 473), a compilation, made during the $9^{\text {th }}$ century, of various texts concerning Frankish historiography which includes also various significant insertions in the Life of Stephen II, « which are pertinent to Frankish affairs or offer a Frankish dimension to papal affairs »; the Liber, as a matter of fact, reaches here only up to Stephen's Life, allowing us to date to the latter's age the version from which it was derived; see also W. Pohl, Das Pappstum..., cit. n. 4, p. I49. 
interpreted previous facts, proves the pliability of the text of the papal biographies and begs for a reflection on the so-called 'Lombard recension' of the Liber. Despite being well known to the scholars of the Liber, many problems remain about it, which cannot be solved here. However, its incomplete study notwithstanding, the text can be useful for the discussion we are pursuing. The Lombard recension - so defined by Louis Duchesne in his edition of the Liber - is a rewriting of the life of Stephen II which systematically blots out the offensive and denigratory expressions directed towards Aistulf and the Lombard people ${ }^{50}$. It's the only biography to which this work of revision was applied, and that means that the author of the recension identified the life of Stephen II as the key biography of pontifical propaganda, the only one truly and heavily offensive towards the Lombards and their king; and it's interesting to note how censure doesn't start from the beginning but slowly builds its momentum, becoming extremely intense only after the Pope's trip to Pavia and France, and reaching its peak on the occasion of the two Frankish military interventions. This version of the Liber also doesn't limit itself to the erasure of the heavy adjectives characterizing Aistulf and the Lombards, or their cowardice (manifested by their flight after having dropped their weapons), but it also expunges the laudatory adjectives used by the biographer for Pippin (cristianissimus, benignissimus, etc.) and for Stephen (beatissimus, coangelicus, etc.). Thus, what we have before us is a bare account of the facts, within which the interventions of God and Christ, even though they are not cancelled, appear as a simple result of inscrutable divine justice. It's obvious, as recently argued by Rosamond McKitterick, that we are observing a version written for the Lombards; which means it was composed in the $8^{\text {th }}$ century, for the inhabitants of the kingdom or, better still, for its ruling class. Given the fact that said version is found within the late eighth- and early ninth-century codex from Lucca, Biblioteca Capitolare 490, if this were the original code from which the others are derived - which is yet to be proved - its provenance would add interest to the entire affair. This is because in Lucca, during those same years, a group of placita were written with a political terminology which is strongly and purposefully Lombard, proving once again the persistence of a social structure that consciously still had its point of reference in the period prior to $774^{5 \mathrm{I}}$. In this group of manuscripts, in any

so R. McKitterick, History and Memory..., p. 52.

${ }^{5} \mathrm{R}$ R. McKitterick, History and Memory..., p. 52: « it makes the text more palatable to Lombard readers by excising the opprobrious comments about Lombards». On the environment based on Lucca and on placita, see S. Gasparri, «Nobiles et credentes omines liberi arimanni ». Linguaggio, memoria sociale e tradizioni longobarde nel regno italico, in Bullettino dell'Istituto storico italiano ed Archivio muratoriano, IO, 2003, pp. 25-5I, especially pp. 32-38. 
case, the presence of twelve Tuscan codes is important, and we can therefore surely attribute this voice to the Lombard Tuscia in general. Even if dating the Lombard recension with certainty after 774 is difficult, it still has interest for our subject since this text circulated in Tuscia during the second half of the 8 th century ${ }^{2}$.

It can be asked if, given this path, we can finally arrive at grasping the 'Lombard-Italica' perspective evoked above. The aphasia on the side of the Lombards, with respect to all the events of the second half of the 8th century is, in fact, almost total, as we have already pointed out. The History of Paul the Deacon stops before that, whatever the reasoning may lie behind this choices3. When Paul deals with the question in the Gesta episcoporum Mettensium, he does it from a Frankish perspective, exhalting the feats accomplished by Charles. Among the admirable actions he carried out, he writes, he submitted the Lombard people, already twice defeated by his father, to his dominion, he captured a king, Desiderius, and threw out the other, Adelchiss, sending him off to Constantinople; and made it "sine gravi proelio", by practicing the rare virtue of exercising large moderation after the victory. In fact, Paul concludes, Charles, having united under his sceptre the Romans, who once were oppressed by the Lombards, submitted all of Italy to a mild domination 54 .

We have returned once again to the voice of the victors, this time that of the Franks. It distinguishes itself with respect to the papal voice by placing emphasis on a feature: a victory without bloodshed. I believe that it isn't by chance that the Frankish annals point out the fact that the Franks passed through the clusae "sine lesione vel aliquo conturbio", and that the abbot Catulf, in a letter written to Charles in the year 775, inserts among his merits the fact that the Lombard army had escaped before him sine publico bello, and that the same extremely opulent city of Pavia had been taken sine cruoris effusioness. Evidently

52 Le Liber pontificalis..., p. CLXXV. If, as François Bougard believes, (thanking him for letting me read his paper, not yet published) it is possible to trace a relationship between the above mentioned recension and bishop Walprand's life, a man whose see was based on Lucca, and who was killed while fighting against the Franks at Aistulf's side in 754, we would have one more reason to place its origins in a Lucca's environment (even if we would have to anticipate the time of its compilation to the first half of the $8^{\text {th }}$ century).

53 R. McKitterick, History and Memory..., pp. 6o-83.

54 Paul the Deacon, Gesta episcoporum Mettensium, ed. G. Pertz, in MGH, Scriptores, II, Berlin I829, p. 265.

55 Annales regni Francorum ...cit. n. 6, p. 36; on Cathuulf, Epistolae variorum Carolo Magno regnante scriptae, in MGH, Epistolae, IV, ed. E. Dümmler, Berolini I895, p. 502; for a general frame of reference, M. Garrison, Letters to a king and biblical exempla: the examples of Cathuulf and Clemens Peregrinus, Early Medieval Europe, 7/3 (1998), pp. 305-328, in which it is demonstrated the fact that Cathuulf was an Irish monk, peregrinus in Frankish lands (p. 306, see also n. 4). 
the Frankish propaganda was feeling how difficult it was to justify bloodshed over a war which certainly wasn't like the war against the pagan Saxons.

Coming back to the Lombard perspective, it may be possible to find a memoir from the year 774 in sources which are not all that predictable. A dating mode appears interesting, in fact, specific to the Tuscan notaries and to those from Lucca in particular at the end of the 8 th century and the beginning of the 9 th. Reference to the conquest of the Lombard kingdom by Charles appears constantly, with expressions such as: regnante domno nostro Carulo rege Francorum et Langobardorum, anno regni eius quo coepit Langobardiam ...; it follows the number of reigning years after the taking of Pavia. With several secondary variations (like the mentioning of Charles's reign "over the Lombard people”), this dating is largely prevalently in use by the notaries from Lucca and appears immediately after the conquest (the first charter is drawn up in Lucca in July of 774); the only important change is Pippin's appearance in the dating starting from 78I, normally simply referred to as king. But, like Charles, he quickly begins to style himself also as patricius romanorum, while the mention of the conquest of Lombardy remains ${ }^{56}$. Italy appears near the latter (not often as an alternative): anno regni eorum (that is of Charles and Pippin), quod Langobardia cepit in Ethalia (respectively thirteenth and sixth), is found written, for example, on a charter of the year 786. The most precise, though, from an historical perspective of the events, are two charters, one from Pisa with the date of 785 and the other from Lucca of the year 794, in which the years of Charles's reign are calculated as in Etalia postquam Papia civitate ingressus est 57.

Necessarily, the charters immediately record the government shifts. It is not strange then if Charles' name immediately appears in the dating. Can the fact that elsewhere different modes of dating are used, which, while obviously referring to Charles, do not highlight the conquest, be considered significant? In fact, a reference such as "from the time Lombardy was taken" is almost completely unknown in the charters of northern Italy. I only know of few examples, from Lombardy and Veneto; normal reference instead is made simply to Charles (and then to Charles and Pippin) "king

56 The extremely numerous charters are edited in Chartae latinae antiquiores s. IX, Italy 20-36, Dietikon-Zürich 199I-1998; the first charter quoted, dated July I $6^{\text {th }}, 774$, is number I047; cfr. also ns. I057, I058 (Chartae, 36, Italy, I7); and 753, 756, 758, 767, 773, ecc. (Chartae, 24, Italy, 5).

57 Respectively, Chartae, 37, Italy, I8, n. I095; Chartae, 38, Italy, I9, n. IIO4; Chartae, 39, Italy, 20, n. II43. 
in Italy", fully returning again to the use prior to the year 774 which didn't use the ethnic predicate ${ }^{8}$.

References to facts or precise situations are also found elsewhere. There is a reference to a precise and traumatic fact in a charter from Friuli of 778 , a donation to the monastery of Sesto in Sylvis near Cividale made by the Frankish duke Massellio, dated "in the second year from when our lord Charles [Charles] most excellent reigning ruler occupied Austria": here the dating element is the revolt of Friuli in the year 776 lead by duke Rotcausus, of which the same Massellio was the successor 59 . We have before us a scrap of local memory of Lombard Austria that left no evident traces in the following charters (from what we can judge, given the destruction of local documentation of that period), but which confirms the importance of the events of $776^{60}$. In the same way, the expression contained in a charter from Piacenza, dated 6th May 774 - "charter of donation made tempore barbarici" - clearly refers to the difficult conditions of the moment, marked by famine and social upheavals and clearly expressed, whether by the first italic Capitulare of Charlemagne, on February 776 , or by a letter of Adrian I to the king of that same year, where the Pope writes about the activity of slave merchants taking advantage of the poverty of entire family units, forced to offer themselves to slavery in order to face somehow the necessitas famis. It is interesting to note that the charter of Piacenza is still dated according to the years of Desiderius and Adelchiss: Pavia had not yet fallen in May, and loyalty in certain areas towards the old rule still resisted ${ }^{6}$.

Nevertheless, the fact remains that the year 774 clearly marked only the dating of Tuscan documents; this did not happen elsewhere. Reference to the conquest remains constant in the charters from Lucca, other than in about ten exceptions, up until Charles's death, also when, with great emphasis, he is referred to with the imperial title. If the conquest is mentioned less frequently elsewhere in Tuscany, the entrance into Italy - or

${ }^{88}$ For example see Chartae, 59, Italy, 3I, n. 3, drawn up in Verona on January I $^{\text {th }}$ 8o6; see also Le pergamene degli archivi di Bergamo, a cura di M. Cortesi, Carte medievali Bergamasche, I, 5, p. 9, May IO ${ }^{\text {th }}, 795$, drawn up near Bergamo.

59 R. Della Torre, L'abbazia di Sesto in Sylvis dalle origini alla fine del '200. Introduzione storica e documenti, Udine 1979, doc. n. 2.

60 For a general frame of reference, S. Gasparri, Il passaggio dai Longobardi ai Carolingi, in Il futuro dei Longobardi. L'Italia e la costruzione dell'Europa di Carlo Magno. Saggi, a cura di C. Bertelli e G. P. Brogiolo, Milano 2000, pp. 25-43.

${ }^{61}$ Codice Diplomatico longobardo, a cura di L. Schiaparelli, Fonti per la storia d'Italia, 63, II, Roma 1933, n. 29I. 
Lombardy - does appear (in Pisa), as a dating element, together with the entrance into Pavia (in the charters of Pistoia and again of Lucca): both ways of dating clearly connected to the conquest ${ }^{62}$. Gradually descending towards the south, the memory of the date of the conquest begins to fade: it is still present in Siena, it is completely lacking in Chiusi. On the contrary, dating appears in the territory of Siena according to Hadrian's years, thus revealing the difficult political transition of those territories situated not very far from the areas already controlled by the church of Rome63. It seems possible, therefore, to identify a way of dating that is typical of the Lombard Tuscia. In general, this type is rather narrative and sensitive to the shifts in government (for example, in its dating Tuscia also conserves the memory of Bernard's return from France and the arrival of Lothar) ${ }^{64}$; a style of dating that speaks more of Lombardy than of Italy and that, above all in northern Tuscia, keeps the memory alive of the events of 774 .

Can we therefore speak of a particular way of remembering the events of the last period of life of the kingdom and of its fall which is exclusive to Tuscia? A way that would express itself not with an original historic narrative but more indirectly - though not less effectively - through the official use of traditional political terminology (the arimanni in the placita of Lucca), the Lombard recension of the Liber and constant reference to the conquest in the dating of the charters? The question mark is obviously necessary but, if it were so, it would be an interesting fact, not only in and of itself but also because Tuscia, in spite of its importance, which is evidenced also by the richness of its archives, completely lacks historical narration from the Lombard or Carolingian ages. But, if what has been said worked, we would be able to identify its voice even though only in an oblique sense. From this standpoint, the Lombard recension can be considered the only historical narrative coming out of Lombard Tuscia.

62 I deem more useful, instead of skimming through the numerous charters considered, which can be easily found in the volumes of the Chartae latinae antiquiores dedicated to Italy, to quote here charter n. II 44 , November I2 $2^{\text {th }} 794$ (vol. 39 cit.), a donation pro anima by the infantulus Adaloald, made secundum constitutionem sancte memoriae Liutprand regi: not only do we find here a reference to a law still in force, but also a hint towards a strong continuity in political memory, if not even towards loyalism. It is worth noting the fact that the area of composition is, once again, Lucca.

${ }_{63}$ See, for example: Chartae, 24, Italy, 5, nn. 760,761, 764, 765, etc., from the year 787 on (Italy 20 ).

64 See, for example: Chartae (2th series, 2002-), 74, Italy, 46, n. 7 (Lucca, s.a. 8I4), on Bernard: anno regni eius, postquam in Dei nomine in Italia reversus est, tertio), and I8 (Pistoia, s.a. 823), on Lothar: anno... postquam accessit in Etalia primo (Chartae, 75, Italy, 47). 
Another text can be identified even in the paucity of the 'Lombard perspective', whose originality results, as for the Lombard recension of the Liber, from reworking a previous text. It is the so-called 'Cassinese continuation' of the History of Paul the Deacon, contained in the famous Cassinese codex Vat. Lat 500I, a manuscript from the beginning of the I $4^{\text {th }}$ century (a copy of a lost manuscript written in c. 974), defined by Walter Pohl as "an especially fascinating example of an almost continuous interest in the history of the Lombard princes in southern Italy" 65 . The "Cassinese continuation", which lacks any link with the history written by Paul the Deacon from the point of view of manuscripts transmission, is a sort of premise to the "History of the Lombards of Benevento" by Erchempert: even if this could be denied on purely stylistic grounds, in substance, it is essentially true ${ }^{66}$. It consists of a brief history of the Lombard kingdom starting from Liutprand, a king of whom, "inter cetera quae gessit magnifica”, many conquests are told. Then Hildeprand is briefly mentioned and, from Ratchis on, the text follows the Liber pontificalis, giv-

65 W. Pohl, History in fragments: Montecassino's politics of memory, in Early Medieval Europe, Io/3, 200I, p. 343-374, in particular about codex Vat. Lat. 500I p. 354-356; the same matter is dealt with more extensively in W. Pohl, Werkstätte der Erinnerung. Montecassino und die Gestalt der langobardischen Vergangenheit, Wien-München 200I, pp. I4-76, in which the codex is described in detail (pp. I8-2I): it includes Erchempert's History of the Southern Lombards, the Chronicon salernitanum, a miscellany of princes' genealogies, poetry and documents, together with the famous Divisio of Longobardia minor between Benevento and Salerno.

66 The definition: Pauli continuatio casinensis (i.e. a continuation of Paul the Deacon's Historia Langobardorum ), was established by Georg Waitz, who edited it under this name in the Scriptores rerum Langobardicarum et Italicarum s. VI-XI, MGH, Hannoverae I878, pp. 198-200. It is true that Erchempert himself introduces his chronicle with a premise, the continuatio, however, not only comes immediately before The History of the Southern Lombards in the codex, but - in this text, which begins after the conquest of the kingdom by Charlemagne, connecting precisely to the end of the continuatio, we find a clear reference to the continuatio itself: it speaks about Arichis, gener iam fati Desideri, the latter, however, is mentioned only in the continuatio and not in Erchempert's work (Erchempert, Historia Langobardorum Beneventanorum, in Scriptores rerum Langobardicarum..., I, p. 235). Lacking, as it is clearly stated in the text, any kind of codicological link to the History composed by Paul the Deacon, we are entitled to ask ourselves if it is still useful to keep this definition of the historiola as a continuation of the Historia Langobardorum, or rather to consider it in the light of its relationship with the other texts within the codex, all of which connected to Lombard history; as a matter of fact, even if the codex was composed only at the end of the $\mathrm{IO}^{\text {th }}$ century, and the so called continuatio and Erchempert' work would be better placed at the end of the previous century, a good portion of the materials it contains can be easily referred back to that period (W. Pohl, Werkstätte ..., p. I8). 
ing maximum room to the reign of Aistulf. The Life of Stephen II then returns at the centre of attention, and it is significant that the version of the Life contained in the Cassinese continuation isn't only abbreviated and paraphrased with respect to the "official" Roman version but that this, too, analogous to the Tuscan-Lombard recension, censures the harshest expressions used against Aistulf (and against the previous rulers) and the Lombards. The only term we find appearing next to a bare exposure of the events, used four times, is persecutio (three times for Aistulf and once for Desiderius). We have before us then a brief "southern-Lombard" version that very concisely narrates the facts (almost completely neutral) including the fall of Pavia, and refers back to the pontificale Romanum for greater details ${ }^{67}$.

It isn't surprising to find this text, not easily datable (it is certainly prior to Erchempert, but by how much?), in an area such as the south, under strong Lombard influence and which remained out of direct Frankish conquest. The codex contains then a Cassinese memory that is also a Lombard one, given that, after all, the later Chronicon Salernitanum is contained within it. The Chronicon, as a matter of fact, is strongly marked in its favour for Desiderius, is against the Franks and one of its heroes is prince Arechis, the only Lombard chief who resisted Charles 68 . It bears remembering that in the Longobardia Minor a narrative of the fall of the reign exists which is fairly ancient, written less than a century after the events, and strongly taking Desiderius' side. It is the famous prologue of the laws of Adelchiss II (the princely onomastic certainly has its significance), which contains a real counter-history of the fall of the kingdom, presenting Charles as an envious and unreliable traitor. Of course, we are in the year 866 and everything is seen from the standpoint of the political confrontation between the same Adelchiss and Louis II, whose involvement in the South - culminating in the capture by the hands of the Lombard prince - was very strong and politically traumatic for the local balance of power. It is in this key that at the court of Benevento Desiderius is retrieved ${ }^{69}$.

The southern Lombard sources of the 9 th century contain some brief narratives of the events of the year 774, which are not hidden but present-

67 Pauli continuatio casinensis ..., p. 200: Si quis autem hoc pleniter nosse desiderat, legat episcopale Romanum; illic discere poterit.

${ }^{68}$ Chronicon Salernitanum...IO-I7, p. 13-22 on Arechis; see also n. I.

69 The prologue is edited in Principum Benedenti Leges, in Le leggi dei Longobardi, a cura di C. Azzara e S. Gasparri, Roma 2005, pp. 306-309 (Latin and Italian text): Carolus Francorum rex, qui sedi eius (scil. Desiderii) invidens et insidians contra eundem subdole et callide agere non refugit (p. 306). 
ed in a neutral way or in an anti-Frankish perspective. We must put this evidence, and in particular Adelchiss' prologue, near the reconstruction of the facts made in Northern Italy by Andrew of Bergamo. This version is clearly laid out to exalt the rulers of Friuli origin, Ratchis and Aistulf, of which Andrew admits to know little, other than that they were audacious and that during their reigns the Lombards were not afraid of anyone. After them, he writes, Desiderius made peace reign thanks also to his political marriage with the Franks and the Bavarians; a peace that was broken only because of Charles's brother, Carloman, "ferebundus ac pessimus", who caused Charles to repudiate his Lombard wife and even causing his own mother to curse him. After Carloman's death, the Pope enters the scene, and he "oppressiones multas patiebat a Langobardis": this is the only negative notation by Andrew in their regard. Fascinating the uncouth Franks with his scholars and poets, the Pope's shrewdness makes Charles forget about the benignitas that Desiderius bestowed upon him, so that he takes the Pope's advice, to get hold of Italy for himself by pulling it away from the Lombards. This is what happened, without much bloodshed, because terror overcomes the Lombards by divine justice (only here one hears the echoes of the Liber pontificalis). After the end of the Lombard kings, Andrew describes the tribulatio of Italy, that he explicitly attributes to the Frankish invasion: "some were killed by the sword, others died from hunger, others by ferocious beasts, to the point that there weren't many survivors in the villages and the cities". Given this situation provoked by the "devastation by the Franks", the people of Veneto and Friuli, guided by duke Rotgaud of Friuli and by the duchies of Treviso and Vicenza, offered resistance to the invaders and even defeated them during a great massacre at the bridge of Livenza. Charles confirmed them in their appointments, forced to giving in to the pacts 70 .

Andrew's account ends here. In reality, things must have happened differently. The rebellion of the year 776 , which I referred to earlier ended with the defeat of Rotgaud and with a very harsh repression whose traces are evident in the surviving documents ${ }^{71}$. Andrew, however, who is not too informed about history in general (he confuses the names of the Popes), brings back, albeit in a confused way, shreds of local memories and, given the precious little we know about the events of those years, it's not to be excluded that there had been a first victorious phase of resistance by Rotgaud. In any case, Andrew's is another "Lombard" version of

70 Andrew of Bergamo, Historia, in Scriptores..., pp. 222-230; for Charles's expedition of 774 and the revolt of Friuli see p. 224.

${ }^{71}$ See supra, n. 60. 
the fall of the kingdom, in significant parallel with what emerges from Southern Italy more or less during the same period. It must be underlined, however, that these two perspectives are not too compatible with each other. The one by Adelchiss is contrary to Louis II, seen as the invader; the other, by Andrew, is written by a supporter of the same Louis II instead.

It is the proof that, already in the 9th century, these versions, more than 'Lombard' in a general sense, are versions from Benevento and Friuli (that is North-eastern Italy). In the first one, Louis is an invader who came from the north; in the second one, Louis is an Italic ruler: and in effect he is rex Langobardorum from the year $844^{72}$. In this sense, these versions are to be read above all in reference to the chronological frame in which they were produced. But, as we have seen above, another local perspective (from Tuscany or even from Lucca) also emerged in reference to the $8^{\text {th }}$ century. The impression that is obtained from these observations is that the versions of the facts broadly speaking about the fall of the kingdom, emerging from the Lombard world and making space for itself in a general picture of writings which were widely dominated by the perspective of the victors, are all regional versions which are in tune with the general, centrifugal process which started up in Lombard Italy in the late 8th century. It's not surprising that these versions emerge from the most important political areas: Friuli, with its powerful aristocracy; Benevento, always having been a solid semi-autonomous principality, historically linked to Friuli; and Tuscia, too, surely having covered a key role and that was also linked to Friuli73. The latter duchy presents itself, also in the sense of political memories, as the only link to the Lombard kingdom during its last period74.

The fragile Lombard-Italic perspective of the events of the year 774, such as the overflowing version by the victors, the Franks and the papacy, all propose themselves then as a deforming mirror of political balances and realities of the period, though, thus confirming the usefulness of studying together, in an ample range of writings, the politics and the memory of the politics, the facts and their interpretation.

${ }^{72}$ Le Liber pontificalis..., II, Paris I892, p. 89 (Life of Sergius II).

73 Let's think, for example, about the two bishops (of Pisa and of Lucca) explicitly involved in the anti-Frankish party, to the extent of being exiled in 774 (Codex Carolinus..., 50, p. 570), the role played by Desiderius himself as duke of Tuscia (Le Liber pontificalis..., I, p. 454), and the presence of the duke of Chiusi among the rebels of 775, and among the most indomitable opponents against the expansion of papal authority in Tuscia (Codex Carolinus..., 57 e 58, p. 582-584).

74 See two works of mine on the subject: one quoted at n. 6o, while the other is S. Gasparri, Istituzioni e poteri nel territorio friulano in età longobarda e carolingia, in Paolo Diacono e il Friuli altomedievale (secc. 